\title{
Upscaling of business model experiments in off-grid PV solar energy in India
}

\author{
Suyash Jolly $\cdot$ Rob Raven $\cdot$ Henny Romijn
}

Received: 27 June 2011/Accepted: 16 March 2012/Published online: 11 April 2012

(C) The Author(s) 2012. This article is published with open access at Springerlink.com

\begin{abstract}
Rapidly developing countries like India face numerous challenges related to social and environmental sustainability, which are associated with their fast economic growth and rising energy demand, climate change, and widening disparities between the rich and the poor. Recently, a number of claims have been made in the literature that the prospects of alternative development pathways in emerging economies in Asia are becoming more likely, and that these economies might even leapfrog Western initiatives. This paper contributes by reporting on the five most visible and established initiatives in the area of off-grid PV solar energy in India, specifically homing in on the innovative business models that are evolving. We develop a new typology of upscaling dimensions in order to analyze these five initiatives. They are found to be quite successful, but have difficulty in terms of reaching the poorest of the poor (deep upscaling) and bringing about required institutional change (institutional upscaling).
\end{abstract}

Keywords India $\cdot$ Social entrepreneurship - Solar PV . Upscaling $\cdot$ Business models

\section{Introduction}

Billions of people live without access to modern energy services. About 1.3 billion people worldwide still do not have access to electricity, and around 2.7 billion people

Handled by Frans Berkhout, Vrije Universiteit, The Netherlands.

S. Jolly $(\bowtie) \cdot$ R. Raven $\cdot$ H. Romijn

School of Innovation Sciences, Eindhoven University

of Technology, Eindhoven, The Netherlands

e-mail: S.Jolly@tue.nl rely on traditional biomass as their primary source of energy (International Energy Agency [IEA] 2011). It is widely accepted that the lack of access to affordable, reliable energy services is a fundamental hindrance to human, social, and economic development and is, thus, a major impediment to achieving the Millennium Development Goals (Srivastava and Rehman 2006). In India, a huge portion of the population still depends on statedistributed and subsidized kerosene, animal and human energy, candles, and traditional biomass such as wood, harvest residues, and cow dung, all of which are associated with substantial issues, such as health problems, energy poverty, burden on state and national financial budgets, and local environmental degradation (Nouni et al. 2009; Rehman et al. 2010).

Like in most emerging economies, the development of a modern electricity supply system in India has been mainly confined to a centralized electricity system based on fossil fuels, especially coal-largely following the development pathways of developed economies. Coal is expected to remain a prominent fuel within the overall electricity mix in India and increase to produce more than $70 \%$ of all power generated in 2030 (IEA 2011). This development trajectory has potentially large benefits, because it can assist in meeting the demands for power by a rapidly growing middle-class population, and it will improve the overall environmental efficiency of the power sector by using state-of-the-art technology (currently, Indian power plants are among the least efficient in the world). However, the choice for further development of an Indian fossilbased system of centralized energy planning and supply also has other very fundamental consequences, especially those related to climate change-inducing effects, exhaustion of fossil fuels resources (and increasing competition for these resources on the global markets), and risks of 
energy security and vulnerability to terrorist attacks. Obviously, pursuing a centralized fossil fuel-based development pathway needs rethinking in the light of these challenges-something that is increasingly acknowledged by countries in both the developed and the developing world.

An important question in this debate is where innovations are coming from that can contribute to more sustainable development pathways. Often cited examples in the West are Germany and Denmark, who are frontrunners in developing and applying renewable energy technologies.

However, recently, a number of claims have been made in the literature that the prospects of alternative development pathways in emerging economies in Asia are also becoming more likely, and that these economies might even leapfrog Western initiatives (Berkhout et al. 2009, 2010; Hultman et al. 2011; Kaplinsky 2011; Romijn and Caniëls 2011; Binz and Truffer 2009). This literature argues that globalization, the development of science and technology capabilities in non-Western countries, and rapidly growing local markets are changing the geography of innovation. A 2010 special report on innovation in emerging markets from The Economist claimed that 'The world's creative energy is shifting to the developing countries, which are becoming innovators in their own right rather than just talented imitators. A growing number of the world's business innovations will in the future come not from "the West" but "the rest", (The Economist 2010). Levi et al. (2010) argue that "India is not likely to offer major breakthroughs, but it will create increasingly cost-effective business models for supplying energy in developing economies." Hence, it is argued that this shift in innovation from the West to the rest has important implications for the direction that innovation processes are taking, with a more direct interest in developing products for the poor and with substantially lower environmental footprints.

These claims are still largely based on anecdotal cases and macro-statistics. This paper aims to contribute to this literature by substantiating some of the claims with new evidence on the five most established and visible solar energy initiatives in India (SELCO, AuroRE, THRIVE, NEST, and D.light Design). Solar energy products such as solar home systems (SHS) and solar lanterns are among the technologies that are gaining increasing attention from social entrepreneurs and social enterprises in India for the electrification of subsistence households in off-grid areas. The five initiatives in this paper, we argue, represent the seeds of a potentially very different development pathway than the centralized, fossil fuel-based electricity system. They are not just different in technological terms, but also in terms of the visions behind the initiatives and the business models applied. All initiatives can be characterized as social enterprises that specifically aim to target poor people and provide them with basic means of energy supply using various financial mechanisms at hand. They have focused on a value proposition through need-based quality products and services, i.e., energy solutions by taking account of usability in hostile environments, affordability, social heterogeneity, inequality (notably due to caste issues), and local customs. Following Berkhout et al. (2010), we characterize these initiatives as 'sustainability experiments' that explore potentially very different socio-technical development pathways compared to those embedded in incumbent socio-technical regimes for centralized, fossil fuel-based electricity supply. In other words, sustainability experiments can be the seeds, and provide learning platforms, for major socio-technical shifts towards substantially cleaner and more socially just energy systems, i.e., a sustainability transition in energy systems.

The five initiatives we study in this paper have all developed rapidly over the past 5-15 years. Still, their revenue or the amounts of energy generated by their products and projects are very small compared to the total energy demand in India or compared to the world solar market. This is not unusual for emerging innovations and makes an analysis of traditional economic indicators such as market share or revenue less useful. Therefore, in this paper, we focus on understanding in what ways these initiatives have upscaled their businesses until now. To understand how these organizations have upscaled, we document in this paper the results of an extensive review of social entrepreneurship literature and relevant development studies literature, which has resulted in a typology of upscaling dimensions for social enterprises.

This paper continues as follows. We first discuss in 'Theoretical building blocks' insights on upscaling from the literature on social entrepreneurship and from development studies. We draw special attention to institutional upscaling, which is perceived as a collective process, and bring in insights from the literature on system innovations, especially strategic niche management (SNM). The section ends with a new typology of upscaling. 'Analytical approach and data collection' is devoted to data collection methods. 'Results' introduces the five Indian initiatives and contains the empirical analysis. The paper ends with 'Conclusions' and sets out relevant elements for future research.

\section{Theoretical building blocks}

Upscaling in social entrepreneurship and development studies

Within the entrepreneurship field as a whole, 'social entrepreneurship' deserves special attention here. Social 
entrepreneurship encompasses the activities and processes undertaken to discover, define, and exploit opportunities in order to enhance social wealth by creating new ventures or managing existing organizations in an innovative manner. Social wealth may be defined broadly to include economic, societal, health, and environmental aspects of human welfare. Essentially, then, one can conceive of social entrepreneurs as key players in sustainability transitions (Witkamp et al. 2011). According to Witkamp et al. (2011), social entrepreneurship is pitted against two extant 'regimes', i.e., the business regime where profit maximization and increasing shareholder value is the major goal, and the civil-society regime where societal objectives take a major role and profit maximization takes a back seat. Social entrepreneurship, therefore, continuously faces tensions between private profit-making and fulfilling societal objectives.

Most social entrepreneurs have an ability to create new connections among people and organizations for new paths, or business models, in which these tensions are managed and societal value is created. In so doing, (social) entrepreneurs also create and develop the institutions and infrastructures needed for development (Garud et al. 2007; Dees 2009; Mair and Marti 2009; Chowdhury and Santos 2010; Zahra et al. 2008, 2009). According to Mair and Marti (2006), Robben (1984), and Sud et al. (2008), entrepreneurs can leverage resources to create new institutions and norms or transform existing ones. Maguire et al. (2004) speak about entrepreneurs' leading efforts to identify political opportunities, frame issues, and induce collective efforts to infuse new beliefs and norms into social structures. In other words, social entrepreneurs can foster development in many different ways: by getting new legislation or regulations passed; getting old legislation or regulations enforced; shifting social norms, behaviors, and attitudes among fellow citizens, corporations, and government personnel; changing the way markets operate; and finding ways to solve problems or meet previously unmet needs.

Several social entrepreneurship studies have discussed the phenomenon of upscaling (Alvord et al. 2004; Bloom and Chatterji 2009; Chowdhury and Santos 2010; Dees 2009; Smith and Stevens 2010). The latter define upscaling as increasing the impact produced by a social-purpose organization to better match the magnitude of the social need or problem it seeks to address. They distinguish upscaling and deep scaling. Upscaling refers to the growth in social value by expanding a current program to other geographic locations. This involves effort and costs in terms of building infrastructure, organizing and developing an ecosystem, obtaining licenses, and educating customers in a new region. Deep scaling refers to focusing energies and resources on achieving greater impact in the same location where the enterprise was started by engaging in activities like improving the quality of services, achieving greater penetration of the target population, finding new ways to serve people, extending services to new people, and developing innovative financial management approaches.

Karamchandani et al. (2009) and Klein (2008) have a somewhat different view. They refer to upscaling as the capacity of the enterprise to expand quickly, effectively, and efficiently. Upscaling can also mean expanding the capacity of the existing business, in the sense of developing resources, building a knowledge base, employing people, developing management systems, and even developing a culture. According to them, upscaling, thus, includes serving more people with the same product within the same region, as well as extending into new markets, i.e., different geographies. In a given situation, the meaning of upscaling, to a large extent, depends on the motivation of the entrepreneur. Some enterprises may focus on developing a specific region in terms of new products and services before scaling geographically, while others may choose to scale into new geographies before venturing into new products and services.

According to Dees et al. (2004), choosing the right path towards broader social impact is a complex matter, since it involves judgment, experimentation, and continuous learning. They develop an approach towards upscaling based on following five Rs, i.e., Readiness, Resources, Receptivity, Risk, and Return. Bloom and Chatterji (2009) suggest the SCALERS model, i.e., Staffing, Communicating, Alliance-building, Lobbying, Earnings-generation, Replicating, and Stimulating market forces. Chowdhury and Santos (2010) suggest that successful upscaling can be achieved by disseminating information through the use of best-practice blueprints or intermediaries such as multilateral organizations and consulting firms.

Since our study is set in an emerging economy with deep-rooted social inequality and poverty in addition to environmental problems, it is pertinent to also examine the literature about development projects, program, and nongovernmental organizations (NGOs) for possibly useful insights about upscaling. Gillespie (2004), Myers (1984), Uvin and Miller (1994), and Uvin (1995) have developed taxonomies of different types of upscaling and paths to achieve it. Uvin (1995) defines 'quantitative scaling' as reaching increasing numbers of people; 'functional scaling' as adding unrelated new activities to existing programs; 'political scaling' as an organization's members participating in or influencing political activities; and 'organizational scaling' as increasing the degree of self-financing through subcontracting. Myers (1984) discusses 'institutional scaling', i.e., involvement in processes and mechanisms for promoting wide stakeholder participation; 
'geographical scaling', i.e., expanding project coverage to other communities/municipalities; 'technological scaling' i.e., broadening a project's technological scope or implementing appropriate technologies to increase productivity; and 'economic scaling', i.e., bringing down unit costs. Other issues that have been discussed include the timing and duration of upscaling. Writers about development have obviously found it difficult to come to grips with the phenomenon. According to Uvin and Miller (1994), "All in all, the literature on upscaling is reminiscent of the Loch Ness monster. It has been sighted enough to make even the skeptical give it a measure of respectability; [but] ... its description is as varied as the people who have written about it."

Institutional upscaling as a collective process

One big complication is that an individual social entrepreneur usually does not have all the competences, resources, and legitimacy that are necessary to create a full infrastructure for a new business. Chowdhury and Santos (2010) point out that, while social entrepreneurs are often successful in establishing effective business models to address problems in their local areas of operation, they face enormous challenges in scaling their operations and achieving greater social returns for constituents such as funding agencies. According to Dees (2010), they need a supportive ecosystem and infrastructure such as targeted financial services, cultural encouragement, and accommodating legal and regulatory mechanisms. These conditions have to be created in concert by a large number of actors, since complex environmental problems are rooted in behaviors, norms, institutions, social structures, and policies. Individual entrepreneurs usually cannot bring about radical institutional change on their own without broad societal support. Rarely do individual actors possess sufficient power, resources, and charisma to bring about institutional change (Garud et al. 2002; Leca et al. 2008).

Therefore, governments, multilateral aid agencies, philanthropic organizations, social investors, financial service organizations, universities, consultants, corporations, bankers, and the media all play an important role in creating conditions that help social entrepreneurs to scale their impact in a timely, significant, and cost-effective way, while, at the same time, prevailing institutions limit the possibilities for institutional entrepreneurship (Dees 2010). Actors are not entirely free, but embedded (Garud and Karnøe 2003; Garud et al. 2007). Entrepreneurs may need to 'run in packs', which means coordinating their actions to simultaneously pursue their own and collective interests, and simultaneously cooperating and competing with others as they develop and commercialize their new ventures (Van de Ven 2005).
As the numbers of entrepreneurs grow, a complex network of cooperative and competitive relationships begins to generate critical mass and produce effective collective action. This infrastructure includes institutional arrangements to legitimate, regulate, and standardize a new technology; public resource endowments of basic scientific knowledge, financing mechanisms, and a pool of competent labor; the creation and development of markets, consumer education and demand, proprietary R\&D, and the development of manufacturing, production, and distribution functions by private entrepreneurial firms to commercialize an innovation for profit. This infrastructure may be developed by superstructure organizations often specializing in coordinating flows of information or coordinating the activities of substructure organizations (Van de Ven 1993, 2005; Jacobsson and Johnson 2000).

Concerted action from different social enterprises and the mobilization of support from multiple other actors in the innovation system for the diffusion and legitimization of new institutional arrangements might, thus, be key requirements for social enterprises that aim to upscale their businesses for solar home systems in India. This is also recognized in a related stream of literature that aims to understand how advocates of radical, potentially more sustainable technologies gain increasing support for their technologies. This literature under the heading of strategic niche management (SNM) is part of evolutionary approaches to understanding systemic transformation in sociotechnical systems towards sustainability (Kemp et al. 1998). In SNM, innovations with promising sustainability characteristics are conceptualized as emerging and developing in 'niches', i.e., emerging institutional environments that provide a (partially) protected space in which actors experiment and incubate promising concepts or prototypes.

The relation between the emerging institutional environment, the space it generates, and the activities performed by innovating actors within that space is conceptualized as cyclic and co-evolutionary. Experiments represent small initiatives in which the earliest stages of socio-technical learning and co-evolution take place. Experiments typically bring together new networks of actors with knowledge, capabilities, and resources, who cooperate in a process of social learning (Berkhout et al. 2010). If successful, experiments generate locally useful lessons, but the experiment's advocates might also try and translate the results into more widely applicable lessons, e.g., through 'internal' networking with similar initiatives by participating in workshops, organizing site visits, and publishing handbooks. Advocates might also collaborate in shaping the institutional environment more directly through 'external' networking, for example, by setting up field-level organizations that lobby governments, user 
groups, science actors, or relevant business actors for beneficial institutional changes.

Socio-technical experiments can encompass a wide range of projects, pilot plants, and demonstration facilities initiated by firms, public research organizations and universities, community and grassroots organizations, and so on (Berkhout et al. 2010). In this literature, experiments are seen as playing a key role in the development of innovations that have the capacity to modify or even replace dominant 'socio-technical regimes'. Regimes constitute the extant social, institutional, and technological fabric of economic activity. Experiments may involve novel technological, actor, and market configurations, and are, therefore, likely to face considerable initial uncertainties, problems, misalignments, and high costs compared with conventional, incumbent regimes to which they offer more sustainable alternatives.

Previous research on the niche development of sustainable energy systems (primarily set in high-income countries) has concentrated on technological experiments and their role in regime change. Few studies have focused on entrepreneurial firms and their importance as prime movers. Entrepreneurs do have an important role in transition processes, since they are agents of creative destruction, with the potential to commercialize sustainable innovations and, consequently, foster the necessary institutional change that favors such innovations (Markard and Truffer 2008).

\section{Analytical approach and data collection}

On the basis of the literature reviewed above, we propose the following dimensions of upscaling for investigating the cases in this paper:

1. Quantitative: upscaling in terms of the number of beneficiaries (Uvin and Miller 1994; Uvin 1995).

2. Organizational: upscaling in terms of expanding the capacity of existing business, i.e., developing resources, building a knowledge base, employing more people, or developing management systems (Klein 2008; Westall 2007).

3. Geographical: upscaling in terms of regional expansion, i.e., serving more people in new regions and extending into new markets (Klein 2008; Karamchandani et al. 2009).

4. Deep: upscaling in the sense of achieving greater impact in an existing location, e.g., through reaching increasingly poorer segments of the population (Rogers et al. 2006; Smith and Stevens 2010).

5. Functional: upscaling in terms of developing new products and services (Klein 2008).
6. Replication: upscaling in terms of the replication of a particular business model, by supporting and incubating new entrepreneurs (Westall 2007).

7. Institutional: upscaling in terms of transforming existing institutions and creating new ones (Maguire et al. 2004; Mair and Marti 2009; Robben 1984; Sud et al. 2008).

In Table 1, we define several empirical indicators for each of these dimensions of upscaling. These dimensions were used to analyze upscaling of the ventures studied in this paper, on the basis of their track record and progress achieved so far. ${ }^{1}$

In order to analyze upscaling of the Indian solar sustainability experiments on each of these seven dimensions, we distinguish 'high' ( +++$)$, 'medium' $(++)$, and 'low' (+) upscaling performance in Table 2, based on an assessment of their achievements to date and retrospective analysis.

The data for the research were collected over a period of three months, from December 2009 to February 2010, in different locations in southern India. Primary data were collected through six interviews and were complemented with secondary data. Interviewees mostly included all company founders and other relevant individuals working for a significant amount of time in the organization. Informants were asked to explain how their organizations were founded, how they grew, how they were organizing their enterprises, and how they planned to upscale. Open questions were used to gather information about the startup process and how the upscaling process went so far. Generally, the initial portion of the interviews focused on the history of the enterprise, along with the challenges faced till today. The later part of the interview was focused on questions informed by Table 1. Interviews generally lasted for around one and half hours to two hours, depending upon the availability of the interviewees. D.light Design could not be contacted for direct interview and most information exchange took place through email. Finally, site visits of the social enterprises added insights about how they were really functioning.

We obtained secondary information through the organizations' websites, presentations in seminars, financial reports, business plans, market analyses, and research documents prepared by the people working in the organizations. In addition, we relied on case studies prepared by other researchers on the organizations, accounts in the published literature, interviews of the entrepreneurs in newspapers and web articles, etc.

\footnotetext{
${ }^{1}$ It should be noted here that these dimensions of upscaling are not mutually exclusive and some might pre-suppose others. For example, substantial quantitative upscaling might only be possible in tandem with organizational upscaling.
} 
Table 1 Indicators for assessing the upscaling performance of sustainability experiments along different dimensions

\begin{tabular}{ll}
\hline $\begin{array}{l}\text { Dimensions of upscaling of } \\
\text { sustainability experiments }\end{array}$ & Empirical indicators \\
\hline $\begin{array}{l}\text { Quantitative } \\
\text { Organizational }\end{array}$ & $\begin{array}{l}\text { Number of beneficiaries/people } \\
\text { Organizational growth, improvement in technical and managerial capacity, development of } \\
\text { infrastructure and resources, development of knowledge base and management systems, diversifying } \\
\text { funding sources and becoming financially self-sustainable, upgrading in the external value chain, } \\
\text { dissemination of knowledge and ideas, research and development activities }\end{array}$ \\
Expansion to new geographical locations (local communities, villages, municipalities, cities, states, and \\
countries) \\
Reaching extremely poor and vulnerable sections of the population, and/or greater impact in the same \\
location where the enterprise was started \\
Increase in the number and type of project activities, new products, and services \\
Creating, incubating, or supporting new entrepreneurs; creating new affiliates; developing new \\
branches; franchising \\
Modification in public policy and regulations at national and international levels, transformation of \\
Replication
\end{tabular}

Table 2 Description of different categories for assessing the upscaling performance of sustainability experiments

\begin{tabular}{|c|c|c|c|}
\hline $\begin{array}{l}\text { Dimensions of } \\
\text { upscaling }\end{array}$ & High upscaling performance $(+++)$ & Medium upscaling performance $(++)$ & Low upscaling performance $(+)$ \\
\hline 1. Quantitative & Reaching millions of beneficiaries & $\begin{array}{l}\text { Reaching hundreds of thousands of } \\
\text { beneficiaries }\end{array}$ & Reaching thousands of beneficiaries \\
\hline 2. Organizational & $\begin{array}{l}\text { Employing more than two hundred } \\
\text { people, having multiple offices, } \\
\text { manufacturing and assembly } \\
\text { facilities, and work places, a large } \\
\text { number of funding sources and } \\
\text { investors, presence in multiple stages } \\
\text { of external value chain, presence of } \\
\text { specialized R\&D centers and } \\
\text { innovation departments for } \\
\text { innovative activities, knowledge } \\
\text { dissemination activities in media }\end{array}$ & $\begin{array}{l}\text { Employing more than one hundred } \\
\text { people, a few offices, manufacturing } \\
\text { and assembly facilities, and work } \\
\text { places, four to five investors and } \\
\text { funding sources, presence in one or } \\
\text { two stages of the external value chain, } \\
\text { R\&D activities but no specialized } \\
\text { departments for such activities, } \\
\text { limited knowledge dissemination } \\
\text { activities in media }\end{array}$ & $\begin{array}{l}\text { Employing less than one hundred } \\
\text { people, confined to one central office } \\
\text { and manufacturing and assembly } \\
\text { facility, dependent on one or two } \\
\text { main investors and funding sources, } \\
\text { presence limited to one stage of the } \\
\text { external value chain, very limited } \\
\text { research and development and } \\
\text { knowledge dissemination activities in } \\
\text { media }\end{array}$ \\
\hline
\end{tabular}

3. Geographical Presence in more than ten countries apart from the home country, around $40-50 \%$ coverage in states/regions in the home country, depending upon the geography of the home country

4. Deep

5. Functional

6. Replication

7. Institutional

Reaching people at the extreme bottom of the pyramid (earning less than 1 USD per day, PPP); significant presence (around 70-80\%) in villages, local communities, and districts in the location from where the enterprise operates

More than ten mainstream products and services, significant number of activities and schemes for customers

Creating, incubating, and supporting hundreds of new entrepreneurs, around hundred branch organizations or affiliates

Bringing powerful social change by
Presence in around five to ten countries, around 20-30\% coverage in states/ regions in the home country, depending upon the geography of the home country

Reaching people close to the bottom of the pyramid (earning between USD 2 and 5 per day, PPP); presence (around $40-50 \%$ ) in villages, local communities, and districts in the location from where the enterprise operates destabilizing existing institutions and creating new institutions
Around ten mainstream products and services, limited activities and schemes for customers

Creating, incubating, and supporting less than hundred of new entrepreneurs, less than one hundred branch organizations or affiliates

Modifying certain institutions through persuasion, lobbying, and collective activities
Presence limited to the home country, around $10-20 \%$ states/regions in the home country, depending upon the geography of the home country

Reaching people above the top of the bottom of the pyramid (earning more than 5 USD per day, PPP); presence (around 10-20\%) in villages, local communities, and districts in the location from where the enterprise operates

Around four to five mainstream products and services, very limited activities and schemes for customers

Creating, incubating, and supporting less than fifty new entrepreneurs, less than fifty branch organizations or affiliates

No significant efforts in modifying or destabilizing existing institutions, no significant activities in lobbying 


\section{Results}

In this section, the case study results are presented. The details of the cases are presented in Table 3.

Our assessment of the upscaling of the five enterprises is summarized in Table 4, based on an analysis of their past performance and ongoing progress. We will elaborate on these upscaling dimensions below.

\section{Quantitative upscaling}

With respect to quantitative upscaling, SELCO has provided sustainable energy products and services to more than 100000 households and is in the process of reaching 200000 households soon. SELCO has also supported 110000 rural homes, 2000 institutions, and 10000 small business cottage industries. It has installed over 125000 solar home lighting systems since 1995 (Ashoka and Hystra 2009; SELCO India 2005, 2007, 2011; AYLLU \& the CSTS 2011). AuroRE has been successful in delivering affordable, reliable renewable energy products and services to more than 80000 Indians. AuroRE's projects include installing 1025 solar water pump sets to farmers in 11 Indian states, such as Punjab, providing solar lanterns to street hawkers in Chennai, and coordinating a rural electrification project in Ladakh using 8700 solar home kits and 6000 lanterns (AuroRE India 2004; AuroRE 2009). THRIVE's long-term mission is to disseminate 100 million lights all over the world. Till now, it has benefitted approximately 160000 people, and most of those are poor and tribal people (Ramani 2010; THRIVE 2010). Noble Energy Solar Technologies Ltd. (NEST) had sold around 78800 solar lanterns till 2008, a gradual increase from 12100 back in 2002. The number of lanterns sold currently is around 90000, of which $80 \%$ are sold in India and the rest are exported. NEST is targeting 1 million solar lanterns in 5-6 years under its unique programs such as Solar Seeding to contribute towards NEST's mission of a kerosene-free world (NEST 2005, 2009; Uppal and Mahendra 2009). D.light Design had sold 1 million solar lanterns in over 30 countries by the end of February 2010. D.light is targeting 50 million people by 2015 and 100 million people by 2020 (D.light 2010, 2011).

\section{Organizational upscaling}

As far as organizational upscaling is concerned, SELCO has had a successful growth over the last 14 years, with a turnover of around USD 1.75 million in FY 2009 and an estimated turnover of USD 3 million in FY 2010. The company made a loss of INR 7.5 million in 2008-2009, but returned to profit in the financial year 2009-2010, earning INR 3.8 million on a revenue of INR 150 million (Ashoka and Hystra 2009; Mukherji 2011; Pullenkav 2010). SELCO has around 170 employees (four regional sales managers, eight senior managers, 21 branch managers, 32 sales executives, 40 customer support executives, and 18 office administrators, in addition to members of the projects, finance and innovation departments, including senior management). SELCO's expansion plans include the achievement of an annual turnover of USD 6 million (SELCO 2009; AYLLU \& the CSTS 2011). AuroRE has quite different plans for organizational upscaling. It is focusing on becoming a knowledge service provider for energy services with core expertise in service provision, consultancy in renewable energy technologies, program and project management, and energy-efficient architecture through workshops, demonstrations, and site visits. Through its experience in renewable energy technologies, AuroRE is also offering its services to European companies looking to certify and carry out field inspections on renewable energy projects and carbon emission reduction projects and programs for their Indian clients (Lamba 2009; Shekhar 2009). THRIVE has generated revenues of around USD 2 million till now. THRIVE is developing a renewable energy center outside Hyderabad for training and demonstration projects in renewable energy. It has plans to start new programs for rural water treatment, rural electrification, rural banks, and rural village outlets. THRIVE also has plans to enter into the solar power generation business in line with the National Solar Mission of the Government of India. In addition, THRIVE is helping many corporate organizations to implement corporate social responsibility (CSR) programs in relation to LED lighting (Ramani 2010; THRIVE 2011). NEST is planning to expand its production, warehousing, and marketing and sales capabilities through an investment of around INR 60 million. It expects revenues of around INR 543 million by 2014-2015 and is targeting an EBIDTA (earnings before interests, taxes, depreciation, and amortization) of around $25 \%$ from the fifth year onwards, i.e., from 2015. Mr. Barki is also planning the manufacturing of solar panels in China to reduce costs (Barki and Barki 2010; Uppal and Mahendra 2009; NEST 2009). D.light Design, on the other hand, is focused on becoming a truly global company. D.light Design has grown to over 70 employees in three years and has offices in the USA, India, Tanzania, China, and Hong Kong. In 2010, D.light Design centralized its product design and international sales in Hong Kong, with plans to move additional corporate functions (D.light 2010, 2011).

\section{Geographical upscaling}

With regard to geographical upscaling, there are unique patterns that are dependent on the chosen business model. 
Table 3 Details of the case studies

\begin{tabular}{|c|c|c|c|c|c|}
\hline Case & SELCO & AuroRE & THRIVE & NEST Solar & D.light Design \\
\hline Founders & $\begin{array}{l}\text { Dr. Harish Hande and } \\
\text { Neville William }\end{array}$ & Hemant Lamba & $\begin{array}{l}\text { Dr. Ranganayakulu } \\
\text { Bodavala }\end{array}$ & D.T. Barki & $\begin{array}{l}\text { Sam Goldman and } \\
\text { Ned Tozun }\end{array}$ \\
\hline Founding year & 1995 & 1998 & 2001 & 1998 & 2007 \\
\hline Location & Bangalore & Auroville, Puducherry & Hyderabad & Hyderabad & New Delhi \\
\hline Vision & $\begin{array}{l}\text { "Empowering the lives } \\
\text { of underserved } \\
\text { populations by } \\
\text { creating linkages } \\
\text { between income } \\
\text { generation and } \\
\text { sustainable energy } \\
\text { services" }\end{array}$ & $\begin{array}{l}\text { "Establishing a } \\
\text { platform for } \\
\text { renewable energy by } \\
\text { integrating service } \\
\text { providers, users, } \\
\text { manufacturers, } \\
\text { financers and policy } \\
\text { makers" }\end{array}$ & $\begin{array}{l}\text { "Provide clean and } \\
\text { reliable lighting } \\
\text { solutions to billions } \\
\text { of people around the } \\
\text { world, improving the } \\
\text { living conditions of } \\
\text { people" }\end{array}$ & $\begin{array}{l}\text { "Eliminating light } \\
\text { poverty from the } \\
\text { world by providing } \\
\text { innovative lighting } \\
\text { solutions to the } \\
\text { poor" }\end{array}$ & $\begin{array}{l}\text { "Enable households } \\
\text { without reliable } \\
\text { electricity to attain } \\
\text { the same quality of } \\
\text { life as those with } \\
\text { electricity and } \\
\text { replacing kerosene } \\
\text { with clean, safe and } \\
\text { bright solar light" }\end{array}$ \\
\hline $\begin{array}{l}\text { Type of } \\
\text { organization }\end{array}$ & $\begin{array}{l}\text { For-profit social } \\
\text { enterprise }\end{array}$ & $\begin{array}{l}\text { Non-profit } \\
\text { organization, } \\
\text { community-based } \\
\text { organization }\end{array}$ & $\begin{array}{l}\text { NGO with separate } \\
\text { commercial } \\
\text { enterprise }\end{array}$ & For-profit enterprise & $\begin{array}{l}\text { Commercial social } \\
\text { for-profit enterprise }\end{array}$ \\
\hline Profitability & $\begin{array}{l}\text { Almost break-even } \\
\text { stage, i.e., neither } \\
\text { profit nor loss; } \\
\text { outstanding loans; } \\
\text { faced heavy financial } \\
\text { losses in 2005-2006 }\end{array}$ & $\begin{array}{l}\text { Break-even stage; } \\
\text { minimum profits } \\
\text { earned through } \\
\text { external projects }\end{array}$ & $\begin{array}{l}\text { Break-even stage with } \\
\text { the commercial } \\
\text { venture Thrive } \\
\text { Energy Technologies } \\
\text { financing the NGO } \\
\text { THRIVE }\end{array}$ & $\begin{array}{l}\text { Break-even stage after } \\
\text { suffering heavy } \\
\text { financial losses in } \\
2003\end{array}$ & $\begin{array}{l}\text { Break-even stage } \\
\text { expected to be } \\
\text { reached in some } \\
\text { years }\end{array}$ \\
\hline Core innovation & $\begin{array}{l}\text { Customized energy } \\
\text { solutions based on } \\
\text { user needs, } \\
\text { installation, and } \\
\text { aftersales services. } \\
\text { Incubation lab for } \\
\text { formulating new } \\
\text { ideas in providing } \\
\text { renewable energy } \\
\text { solutions }\end{array}$ & $\begin{array}{l}\text { Energy Service } \\
\text { Provider (ESCO) } \\
\text { acting as a system } \\
\text { integrator and } \\
\text { installer providing } \\
\text { high-quality } \\
\text { renewable energy } \\
\text { systems, research, } \\
\text { and development of } \\
\text { various energy } \\
\text { technologies }\end{array}$ & $\begin{array}{l}\text { Research and } \\
\text { development } \\
\text { activities on LED } \\
\text { technology }\end{array}$ & $\begin{array}{l}\text { Design, development } \\
\text { of new and } \\
\text { innovative solar } \\
\text { energy products; } \\
\text { manufacturing and } \\
\text { assembly facilities } \\
\text { for polycrystalline } \\
\text { PV technology }\end{array}$ & $\begin{array}{l}\text { Product design } \\
\text { capabilities with } \\
\text { competencies in } \\
\text { R\&D and high- } \\
\text { volume } \\
\text { manufacturing }\end{array}$ \\
\hline $\begin{array}{l}\text { Organizational } \\
\text { setup }\end{array}$ & $\begin{array}{l}\text { Headed by Dr. Harish } \\
\text { Hande and several } \\
\text { people in senior } \\
\text { management; around } \\
170 \text { employees; } \\
\text { network of energy } \\
\text { service centers, } \\
\text { regional branch } \\
\text { offices, and } \\
\text { headquarters in } \\
\text { Bangalore }\end{array}$ & $\begin{array}{l}\text { Headed by Hemant } \\
\text { Lamba, Kavit Kumar } \\
\text { looks at financial } \\
\text { administration } \\
\text { matters, and Hemant } \\
\text { Shekhar works at } \\
\text { various research } \\
\text { projects. Several } \\
\text { voluntary employees }\end{array}$ & $\begin{array}{l}\text { Headed by Dr. } \\
\text { Ranganayakulu } \\
\text { Bodavala, along with } \\
\text { Mr. Sreekamal } \\
\text { Bandopadhyaya as } \\
\text { the project manager } \\
\text { and Mr. Satish } \\
\text { Somepalli as the } \\
\text { director of finance. } \\
94 \text { employees in } \\
\text { manufacturing and } \\
\text { production and } 142 \\
\text { employees in field } \\
\text { operations; strong } \\
\text { team of engineers } \\
\text { and technicians }\end{array}$ & $\begin{array}{l}\text { Headed by Mr. D.T. } \\
\text { Barki, with Bharat } \\
\text { Barki as the director } \\
\text { of NEST; Jagan } \\
\text { Mohan Rao, K. } \\
\text { Vasudeva, J.V. } \\
\text { Ramana, Manohar } \\
\text { Reddy as important } \\
\text { stakeholders; around } \\
45 \text { employees; } \\
\text { currently around } 15 \\
\text { direct employees } \\
\text { work at the head } \\
\text { office and workshop } \\
\text { in Hyderabad and } 7 \\
\text { people working in } \\
\text { the factory at } \\
\text { Bangalore }\end{array}$ & $\begin{array}{l}\text { Headed by Don Tice, } \\
\text { with around } 70 \\
\text { employees in four } \\
\text { offices across the } \\
\text { world in New Delhi, } \\
\text { Tanzania, Shenzhen } \\
\text { and Hong Kong, } \\
\text { Cayman Islands, } \\
\text { USA; } 25 \text { people } \\
\text { working in India, } 15 \\
\text { in China, } 11 \text { in } \\
\text { Tanzania, } 2 \text { part- } \\
\text { time staff in USA }\end{array}$ \\
\hline
\end{tabular}


Table 3 continued

\begin{tabular}{|c|c|c|c|c|c|}
\hline Case & SELCO & AuroRE & THRIVE & NEST Solar & D.light Design \\
\hline $\begin{array}{l}\text { Business model } \\
\text { (product and } \\
\text { services, } \\
\text { customer } \\
\text { interface, } \\
\text { infrastructure } \\
\text { management, } \\
\text { financial } \\
\text { aspects) }\end{array}$ & $\begin{array}{l}\text { Local assembly } \\
\text { operations which } \\
\text { source different } \\
\text { components from } \\
\text { wholesalers and } \\
\text { distributors such as } \\
\text { TATA BP Solar, } \\
\text { located in Bangalore, } \\
\text { depending upon the } \\
\text { price of components } \\
\text { Network of regional } \\
\text { branch offices and } \\
\text { energy service } \\
\text { centers which have } \\
\text { teams of technicians, } \\
\text { managers, and } \\
\text { salesmen and } \\
\text { actively engaged in } \\
\text { selling, installing, } \\
\text { and servicing energy- } \\
\text { related products and } \\
\text { services } \\
\text { investors, } \\
\text { development } \\
\text { organizations, and } \\
\text { funding from CDM } \\
\text { mechanism } \\
\text { developed for } \\
\text { consumer financing } \\
\text { with linkages with } \\
\text { various financial } \\
\text { institutions, } \\
\text { including } \\
\text { commercial banks, } \\
\text { regional rural banks, } \\
\text { rural farmer } \\
\text { cooperatives, and } \\
\text { microfinance } \\
\text { institutions }\end{array}$ & $\begin{array}{l}\text { Energy Service } \\
\text { Provider (ESCO) } \\
\text { acting as a system } \\
\text { integrator and } \\
\text { installer; acting as a } \\
\text { maintenance and } \\
\text { service company } \\
\text { offering maintenance } \\
\text { services to end users } \\
\text { No external financing } \\
\text { due to regulations of } \\
\text { the Auroville } \\
\text { community; PV solar } \\
\text { business of Auroville } \\
\text { runs on a commercial } \\
\text { basis by earning } \\
\text { revenue from } \\
\text { projects; runs on a } \\
\text { non-profit non-loss } \\
\text { basis }\end{array}$ & $\begin{array}{l}\text { Importation of } \\
\text { microchips from the } \\
\text { USA, batteries from } \\
\text { China, LED lights } \\
\text { from Japan, and local } \\
\text { assembly operations } \\
\text { in Hyderabad for the } \\
\text { development of solar } \\
\text { lanterns; network of } \\
\text { energy kiosks for } \\
\text { reaching rural people } \\
\text { Partnerships with } \\
\text { various NGOs, } \\
\text { organizations like the } \\
\text { United Nations, } \\
\text { World Bank; } \\
\text { customized financing } \\
\text { mechanisms for } \\
\text { customers through } \\
\text { partnerships with } \\
\text { microfinance } \\
\text { institutions, women's } \\
\text { groups, rural banks, } \\
\text { and international } \\
\text { financial institutions } \\
\text { Investment in the form } \\
\text { of grants from the } \\
\text { World Bank and } \\
\text { other international } \\
\text { agencies; revenue } \\
\text { from carbon credits } \\
\text { through the } \\
\text { UNFCCC CDM } \\
\text { mechanism }\end{array}$ & 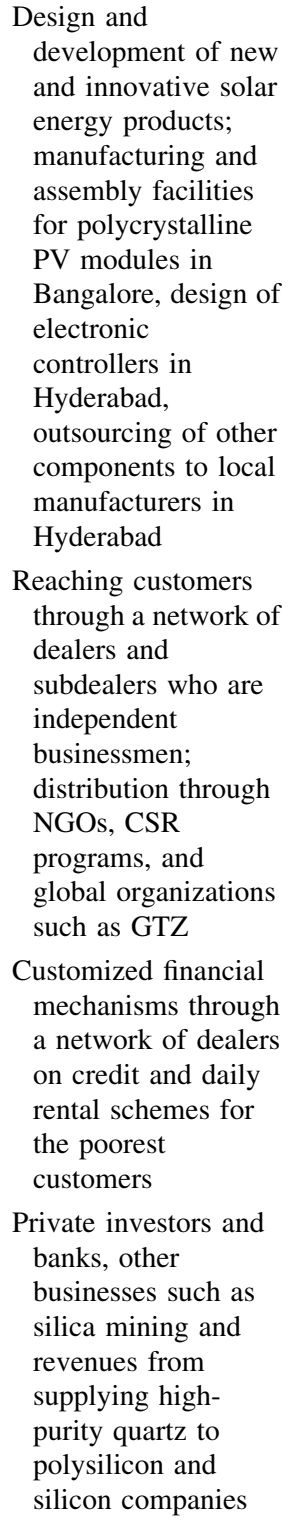 & $\begin{array}{l}\text { Sales and marketing } \\
\text { and R\&D division in } \\
\text { New Delhi, East } \\
\text { Africa's sales office } \\
\text { in Dar es Salaam, } \\
\text { Tanzania, product } \\
\text { design and } \\
\text { international sales } \\
\text { and marketing } \\
\text { division in Hong } \\
\text { Kong; } \\
\text { manufacturing and } \\
\text { production in } \\
\text { Shenzhen, China } \\
\text { Commercial dealers } \\
\text { and distributors and } \\
\text { the open market for } \\
\text { product sales; } \\
\text { partnerships with } \\
\text { NGOs and } \\
\text { microfinance } \\
\text { institutions } \\
\text { Investment from } \\
\text { venture capital, } \\
\text { social investors, } \\
\text { grant from } \\
\text { foundations, } \\
\text { UNFCCC CDM } \\
\text { mechanism; United } \\
\text { States Securities and } \\
\text { Exchange } \\
\text { Commission }\end{array}$ \\
\hline $\begin{array}{l}\text { Threat to } \\
\text { business model }\end{array}$ & $\begin{array}{l}\text { High variability in the } \\
\text { price of components, } \\
\text { i.e., cost of the } \\
\text { installed PV } \\
\text { modules, batteries, } \\
\text { and converters for } \\
\text { solar home systems; } \\
\text { false promises by the } \\
\text { government for grid } \\
\text { electricity to poor } \\
\text { people; need for } \\
\text { local technicians }\end{array}$ & $\begin{array}{l}\text { Lack of finances and } \\
\text { workforce; high } \\
\text { subsidies for } \\
\text { conventional fuels }\end{array}$ & $\begin{array}{l}\text { Lack of research and } \\
\text { development and } \\
\text { large-scale } \\
\text { manufacturing of } \\
\text { LED technology in } \\
\text { India; rapid } \\
\text { fluctuations in LED } \\
\text { prices; intellectual } \\
\text { property issues }\end{array}$ & $\begin{array}{l}\text { High distribution } \\
\text { costs; presence in } \\
\text { multiple parts of the } \\
\text { PV value chain } \\
\text { makes it difficult to } \\
\text { balance } \\
\text { manufacturing, } \\
\text { sales, marketing, } \\
\text { and distribution }\end{array}$ & $\begin{array}{l}\text { High import costs for } \\
\text { solar energy } \\
\text { components; high } \\
\text { storage and } \\
\text { distribution costs; } \\
\text { gaining good } \\
\text { product distribution } \\
\text { capabilities in rural } \\
\text { areas; intellectual } \\
\text { property issues due } \\
\text { to cheap substitutes } \\
\text { on the market }\end{array}$ \\
\hline
\end{tabular}

SELCO is focusing on expanding geographically in five Indian states neighboring Karnataka, including Maharashtra, Tamil Nadu, Kerala, and Andhra Pradesh. By the end of financial year 2010-2011, it is expected that SELCO would be present in 16 districts of Karnataka, 3 districts of Kerala, 4 districts of Gujarat, and 3 districts in states like 
Table 4 Upscaling performance in different dimensions for different case studies

\begin{tabular}{|c|c|c|c|c|c|}
\hline Dimensions of upscaling & SELCO & AuroRE & THRIVE & NEST & D.light Design \\
\hline Quantitative & ++ & ++ & ++ & ++ & +++ \\
\hline Organizational & +++ & + & ++ & ++ & ++ \\
\hline Geographical & + & ++ & +++ & +++ & +++ \\
\hline Deep & ++ & ++ & ++ & ++ & ++ \\
\hline Functional & +++ & ++ & +++ & +++ & ++ \\
\hline Replication & +++ & ++ & +++ & ++ & ++ \\
\hline Institutional & ++ & + & + & + & + \\
\hline
\end{tabular}

Maharashtra and Andhra Pradesh (SELCO 2009, 2010). However, SELCO has found it difficult to expand geographically across different Indian states due to the lack of spillover learning across different states and the lack of financial institutions with whom SELCO can partner with. At the same time, SELCO does not want to use the franchise system to sell its products and services, as the reputation of its brand depends on services and it is more difficult to guarantee the same quality of service from franchises. Hence, SELCO has decided to only move into a new region if there are good contacts there both for the dissemination of information and for providing good services (Mukherji 2011; SELCO 2009; SELCO India 2011). AuroRE has been successful in delivering affordable, reliable renewable energy products and services across 12 Indian states, such as Andaman and Nicobar Islands, Tamil Nadu, Pondicherry, Karnataka, Kerala, Orissa, Jammu and Kashmir, and Gujarat (AuroRE 2004). THRIVE, NEST, and D.light Design are the most internationally oriented of the five cases. THRIVE has established an international geographical reach due to the support from various groups and organizations around the world. At present, THRIVE is strongly established in Indian states like Orissa, Andhra Pradesh, Jharkhand, Bihar, Maharashtra, and Manipur, and countries such as Afghanistan, Cambodia, Bangladesh, Ethiopia, and Kenya (Ramani 2010; THRIVE 2011). NEST also has a wide geographical presence in India, with a network of 70 dealers in different states in India. Globally, NEST has expanded its operations to countries such as the UK, Sudan, Sri Lanka, Japan, Australia, Malaysia, Kenya, Nigeria, Malawi, Tanzania, Fiji, Belize, Bolivia, El Salvador, and Puerto Rico. Now, NEST has plans to reach other countries such as Nigeria, Somalia, Central America, Pakistan, Australia, and China (Barki and Barki 2010; Barnhill et al. 2011; NEST 2009). D.light Design has also developed a strong distribution in around 32 countries and has built additional distribution outlets in places such as South East Asia, Latin America, Pacific Islands, and West Africa. D.light Design is planning to expand further in India, Bangladesh, and East Africa, with the goal of selling millions of lighting products (D.light 2010, 2011; Shukla and Bairiganjan 2011).

\section{Deep upscaling}

With respect to deep scaling, it is found that the ventures discussed generally have not been able to reach increasingly poor segments of the population, i.e., going deeper down the economic strata in their existing locations, although it has to be said that they have developed rental schemes and special financial mechanisms to reach people at the base of the pyramid. The key problem is that commercial approaches, though appropriate in many cases, are unable to reach the extreme poor, i.e., those who cannot be offered loans from rural banks and microfinance institutions due to the lack of any kind of assets (Shukla and Bairiganjan 2011). For reaching the very poorest segments of the population, there is, thus, a need for mobilizing more financial support through government grants, carbon finance through the CDM mechanism, and support from international financial institutions (D.light 2009). This constitutes a major challenge for the future.

Functional upscaling

The ventures are generally performing well in terms of functional upscaling. SELCO has created new solar energy-related businesses such as PV-powered batterycharging businesses which supply single-lamp systems for both street vendors and poor homes, PV power for sewing machines to increase the productivity of sewing businesses, PV-powered soldering irons for TV repair, and small PV-powered silk looms. SELCO is also in the process of developing a cheap, improved cooking stove for its clients. It is also diversifying into energy services other than solar ones, such as thermal, efficient cooking, biogas provision, and drying, to its existing clients. Thus, SELCO is looking to become a complete energy provider, from just a solar lighting provider. In addition, SELCO is partnering with two organizations for multiple service-based e-kiosks in rural areas of India, which will be run on solar power, and providing solar-based power solutions for water purification (Datta 2009; Hande 2010; India Knowledge@Wharton 2010; AYLLU \& the CSTS 2011). AuroRE is developing 
new products such as LED/CFL-based home lighting lanterns, as well as solar-powered reverse osmosis systems to purify drinking water. AuroRE is also working on new products such as an improved solar rice cooker, a solar lantern, and solar home lighting kits. In addition, AuroRE has developed the mission TEJAS, which is a platform of exchange and development for solar energy technologies by bringing together lighting designers, product manufacturers, NGOs, administrative bodies, financial institutions, and corporate/industrial R\&D players (AuroRE 2009; Lamba 2009; Shekhar 2009). THRIVE has introduced additional forms of lights that are useful to the villages, like street lights, task lights, etc., at very economical rates. THRIVE is looking for a major share in niche markets such as street lighting, boarding, and institutional lighting (Ramani 2010; THRIVE 2011). Similarly, NEST is planning to increase its product portfolio by developing new solar street lights, solar-powered fans, mini solar desk lamps, etc. (Barki and Barki 2010; NEST 2009). D.light Design has developed several new products, such as a premium solar lantern with four brightness settings, affordable solar lanterns with $360^{\circ}$ lighting and quality solar task lamps, and D.light S1, which is one of the cheapest solar lanterns at a price of around USD 8 (D.light 2011).

\section{Replication}

As far as replication is concerned, SELCO is trying to start an incubation system for new entrepreneurs and business associates, and aims to have 100 additional business associates. These business associates are rural youths, who would have a chance to create sustainable livelihoods for themselves by providing energy services through SELCO's products and services to poor people through their own businesses, keeping the SELCO management as board advisors. SELCO has also set up a USD 3 million fund to help new entrepreneurs planning to start new enterprises for energy services in different geographical locations. SELCO has already helped to create more than 25 entrepreneurs who are serving 750 clients by providing solar lighting to street vendors, home-based workers, and small businesses (Hande 2010, 2011; India Knowledge@Wharton 2009, 2010; Mukherji 2011; AYLLU \& the CSTS 2011). AuroRE is also focused on creating solar entrepreneurs. Such ventures can become financially sustainable in different ways, such as hiring out solar lanterns to market traders or supplying and installing solar water pumps to farms. AuroRE is aiming to set up a whole chain of local energy entrepreneurs by effectively providing them with managerial, technical, and financial backup. It is also training several people and developing a network of sustainable enterprises among economically deprived communities. This includes the training of at least 250 people in the installation and maintenance of PV solar systems (AuroRE 2004; AuroRE India 2004). THRIVE is encouraging village entrepreneurship by promoting solar light entrepreneurs and LEDbased home lighting with the intention to create micro, small, and medium energy service enterprises for manufacturing, selling, and servicing LED lamps. THRIVE has also proposed alternative energy kiosks in villages in which users can walk and get light charges for a token fee and enjoy continued service and maintenance of light. The kiosks are run by local youths with minimum education like matriculation and basic training in electronics and mobile phone usage (Ramani 2010; THRIVE 2011). NEST is developing small businesses which manufacture charge controllers and plastic works exclusively for NEST. In addition, it is developing and supporting entrepreneurs in villages for the distribution of its products (Uppal and Mahendra 2009; NEST 2009). D.light Design has built a distribution base of 1500 rural entrepreneurs. Each rural entrepreneur handles around 2000 households who also source products from dealers (Raja 2009).

\section{Institutional upscaling}

From the literature review in "Theoretical building blocks," it was found that institutional upscaling is generally beyond the scope of individual enterprises and requires concerted action from a critical mass of entrepreneurs. All enterprises except SELCO score low in this respect. SELCO, in the past, has lobbied government institutions such as the Reserve Bank of India to reduce the procedural bureaucracy of foreign investment from social investors abroad to firms such as SELCO (Alexander 2009; India Knowledge@Wharton 2010). All the enterprises discussed found it difficult to be involved in institutional upscaling. Some of the key institutional barriers mentioned include high subsidies for fossil fuels and high taxes for solar energy products, lack of consumer finance from financial institutions, and other regulative barriers. Most enterprises have advised government officials about, and have even lobbied against, high subsidies for fossil fuels, but their efforts have not resulted in any major institutional changes. Enterprises have also found it time-consuming to engage in trying to bring in institutional changes, since this may make them lose focus from their primary work-the day-to-day functioning of the enterprise and meeting the needs of their customers (Alexander 2009; Barki and Barki 2010; Lamba 2009; Ramani 2010).

\section{Conclusions}

On the whole, the discussion of the upscaling achievements of the five solar PV ventures discussed in this paper 
demonstrates that, currently, there are, indeed, several promising experimental activities ongoing in India that signal a very different way of electricity provision.

One striking similarity between the initiatives is that they are conceived and nurtured by visionary people with creative ideas and drive, who have conceived innovative business models that manage to balance societal aims with the exigencies of financial sustainability. At the same time, the way in which the different ventures achieve this balance is found to vary a great deal. The most important issue seems to be that strategy and structure should reflect-and continue to reflect-the particular idiosyncratic vision and mission of the leadership. A broad multidimensional classification of upscaling as used in this paper, which is capable of capturing heterogeneity in performance, strategies, structures, and plans, is, therefore, found to be a suitable research tool for getting a better grip on the 'Loch Ness monster'. It has to be said, though, that a research approach like this one should, thus, be considered as primarily useful for conducting a broad-sweep assessment aimed at mapping upscaling in innovative sustainabilitycentered activities in particular emerging fields. It is likely to be less useful for a detailed microlevel comparison of different individual cases, because of the inevitable subjectivity involved in translating research data/findings into particular scores in the classification scheme.

The analysis conducted in this paper raises several other pointers for policy and research. Our results indicate that the ventures are generally well on track towards upscaling, but that they lag behind in terms of two crucial-and closely intertwined-dimensions: (a) reaching the poorest of the poor (deep scaling) and (b) effecting broader institutional change (institutional upscaling). Reaching the people at the very base of the pyramid is, indeed, a massive challenge, and it does not help that many Western corporations and even major international development organizations are currently advocating the use of for-profit commercial approaches even for this target group. There is very little evidence on the ground that such base of the pyramid approaches can actually produce win-win results at the required massive scale (Arora and Romijn 2011). A better strategy could lie in the facilitation and coordination of nonprofit social-oriented ventures like the ones considered in this paper, including through making available more financial resources at appropriate conditions from national and international sources, and through encouraging the formation of supportive enterprise networks in which different partners support each other by executing complementary activities (Wheeler et al. 2005). However, whether or not that will assist these ventures in actually reaching the poorest of the poor still needs to be seen.

As far as the institutional dimension of upscaling is concerned, it would be particularly useful to complement the type of analysis conducted here with an assessment at a higher analytical level in order to explore the meaning and dynamics of 'collective upscaling' more comprehensively. A 'meso-level' investigation can reveal a more complete picture of pivotal institutional upscaling barriers faced by social entrepreneurs in the conduct of their sustainability experiments, and on the key factors that prevent different actors in an emerging 'innovation system' such as solar PV from acting in concert and achieving the critical mass needed for effecting change in the institutional sphere. Interviews and literature study focused on individual entrepreneurial ventures as conducted for the present paper miss out a substantial part of these issues, because their scope is restricted to the individual entrepreneur's activities, strategies, and point of view. In this respect, the adoption of multilevel analytical frameworks (such as that used in SNM and some sectoral innovation systems approaches), which set an analysis of innovation dynamics at the level of individual experiments and emerging niches within a broader overarching socio-technical context, would be a useful step in this direction.

Acknowledgments We would like to thank the two anonymous reviewers and the editors for their valuable feedback on earlier versions of this paper. We also thank the interviewees for sharing their insights with us. This research was partly funded by the Netherlands Organisation for Scientific Research (NWO) under the WOTRO Science for Global Development scheme.

Open Access This article is distributed under the terms of the Creative Commons Attribution License which permits any use, distribution, and reproduction in any medium, provided the original author(s) and the source are credited.

\section{References}

Alexander S (2009) Interview, 23 December 2009, Bangalore Alvord SH, Brown LD, Letts CW (2004) Social entrepreneurship and societal transformation: an exploratory study. J Appl Behav Sci 40(3):260-282

Arora S, Romijn HA (2011) The empty rhetoric of poverty reduction at the base of the pyramid. Organization. doi:10.1177/13505084 11414294 (in press)

Ashoka, Hystra (2009) Access to energy for the base of the pyramid. http://www.ashoka.org/story/6072. Accessed 20 Apr 2010

AuroRE (2004) Creating 'solar' entrepreneurs. infochange environment. http://infochangeindia.org/environment/stories-of-change/ aurore-creating-solar-entrepreneurs.html. Accessed 14 Mar 2011

AuroRE (2009) Auroville renewable energy 2009. http://www.aurore. in. Accessed 13 Jul 2011

AuroRE India (2004) Solar power for communities, farmers and market traders across India. The Ashden Awards for Sustainable Energy. http://www.ashdenawards.org/winners/aurore. Accessed 20 Jan 2010

AYLLU \& the CSTS (2011) CSTS \& AYLLU energy map. Clean energy for the underserved. Selco. http://energymap-scu.org/ selco/. Accessed 10 Aug 2011 
Barki B, Barki DT (2010) Interview, 27 January 2010, Hyderabad

Barnhill C, Chansavang A, Jayanthi T, Liu W-C, Marquis E (2011) Noble Energy Solar Technologies. Report, Innovation for Humanity Project, John Hopkins Carey Business School, Baltimore

Berkhout F, Angel D, Wieczorek AJ (2009) Asian development pathways and sustainable socio-technical regimes. Technol Forecast Soc Chang 76:218-228

Berkhout F, Verbong GPJ, Wieczorek AJ, Raven RPJM, Lebel L, Bai $X$ (2010) Sustainability experiments in Asia: innovations shaping alternative development pathways? Environ Sci Policy 13(4):261-271

Binz C, Truffer B (2009) Leapfrogging in infrastructure sectorsidentifying transition trajectories towards decentralized wastewater treatment in China. Paper presented at the 2009 DRUID conference in Copenhagen

Bloom PN, Chatterji AK (2009) Scaling social entrepreneurial impact. Calif Manag Rev 51(3):114-133

Chowdhury I, Santos MF (2010) Scaling social innovations: the case of Gram Vikas. http://papers.ssrn.com/sol3/papers.cfm?abstract id=1553070. Accessed 13 Apr 2010

Datta N (2009) Sun dialing. Outlook Business. http://business.outlook india.com/article.aspx?261397. Accessed 5 Feb 2010

Dees JG (2009) Social ventures as learning laboratories. Innovations. Special Edition for the World Economic Forum Annual Meeting 2009, pp 11-15

Dees JG (2010) Social entrepreneurs. Creating large-scale change: not 'can' but 'how'. McKinsey and Company. http://whatmatters. mckinseydigital.com/social_entrepreneurs/creating-large-scalechange-not-can-but-how-. Accessed 10 Aug 2010

Dees JG, Anderson BB, Wei-Skillern J (2004) Scaling social impact. Strategies for spreading social innovations. Stanford Soc Innov Rev 1(4):24-32

D.light (2009) D.light Rural Lighting Project. http://cdm.unfccc. int/Projects/DB/TUEV-SUED1245158196.62/view. Accessed 17 Jun 2010

D.light (2010) D.light Design, India and global 2010. Case study summary. The Ashden Award for Sustainable Energy. http://www. ashdenawards.org/winners/Dlight10. Accessed 10 Dec 2010

D.light (2011) D.light International. http://www.dlightdesign.com/ home_global.php. Accessed 08 Jul 2011

Garud R, Karnøe P (2003) Bricolage versus breakthrough: distributed and embedded agency in technology entrepreneurship. Res Policy 32:277-300

Garud R, Jain S, Kumaraswamy (2002) Institutional entrepreneurship in the sponsorship of common technological standards: the case of Sun Microsystems and Java. Acad Manag J 45(1):196-214

Garud R, Hardy C, Maguire S (2007) Institutional entrepreneurship as embedded agency: an introduction to the special issue. Org Stud 28:957-969

Gillespie S (2004) Scaling up community-driven development: a synthesis of experience. FCND discussion paper no. 181. IFPRI, Washington, DC

Hande H (2010) Can solar bring power to India's rural poor? Qn, a publication of the Yale School of Management. http://qn.som.yale. edu/content/can-solar-bring-power-india\%E2\%80\%99s-rural-poor. Accessed 16 Jul 2011

Hande H (2011) India's growing energy disparity—need for energy inclusion and social innovation. World Economic Forum Blog. http://www.forumblog.org/socialentrepreneurs/2011/05/indiasgrowing-energy-disparity-need-for-energy-inclusion-and-socialinnovation.html. Accessed 15 Oct 2011

Hultman NE, Pulver S, Pacca S, Saran S, Powell L, Romeiro V, Benney T (2011) Carbon markets and low-carbon investment in emerging economies: a synthesis of parallel workshops in Brazil and India. Energy Policy 39:6698-6700
India Knowledge@Wharton (2009) Rising Sun: India's solar power initiatives are shining brighter. http://knowledge.wharton. upenn.edu/india/article.cfm?articleid=4437. Accessed 20 Mar 2010

India Knowledge@Wharton (2010) Harish Hande of SELCO India: shedding light on India's undeserved markets. http://knowl edge. wharton. upenn.edu/india/article.cfm?articleid=4460. Accessed 26 Apr 2010

International Energy Agency (IEA) (2011) World Energy Outlook 2011, Paris

Jacobsson S, Johnson A (2000) The diffusion of renewable energy technology: an analytical framework and key issues for research. Energy Policy 28:625-640

Kaplinsky R (2011) Schumacher meets Schumpeter: appropriate technology below the radar. Res Policy 40:193-203

Karamchandani A, Kubzansky M, Frandano P (2009) Emerging markets, emerging models: market based solutions to the challenges of global poverty. Monitor Group, India

Kemp R, Schot J, Hoogma R (1998) Regime shifts to sustainability through processes of niche formation: the approach of strategic niche management. Technol Anal Strateg Manag 10(2):175-198

Klein MH (2008) Poverty alleviation through sustainable strategic business models. essays on poverty alleviation as a business strategy. Erasmus Research Institute of Management (ERIM) $\mathrm{Ph} . D$. Series Research in Management 135

Lamba H (2009) Interview, 24 December 2009, Auroville, Puducherry

Leca B, Battilana J, Boxenbaum E (2008) Agency and institutions: a review of institutional entrepreneurship. Working Paper 08-096. http://egateg.usaidallnet.gov/sites/default/files/Review\%20of\%20 Institutional\%20Entrepreneurship.pdf

Levi M, Economy EC, Neil SO, Segal A (2010) Globalizing the energy revolution: how to really win the clean-energy race. Foreign Affairs

Maguire S, Hardy C, Lawrence TB (2004) Institutional entrepreneurship in emerging fields: HIV/AIDS treatment advocacy in Canada. Acad Manag J 47(5):657-679

Mair J, Marti I (2006) Social entrepreneurship research: a source of explanation, prediction, and delight. J World Bus 41:36-44

Mair J, Marti I (2009) Entrepreneurship in and around institutional voids: a case study from Bangladesh. J Bus Ventur 24:419-435

Markard J, Truffer B (2008) Technological innovation systems and the multi-level perspective: towards an integrated framework. Res Policy 37:596-615

Mukherji S (2011) SELCO: solar lighting for the poor. Case study, UNDP, Growing Inclusive Markets. http://www.growinginclus ivemarkets.org/media/cases/India_SELCO_2011.pdf. Accessed 30 Oct 2011

Myers GC (1984) The Consultative Group on Early Childhood Care and Development. Going to scale. Paper prepared for UNICEF for the Second Inter-Agency Meeting on Community-based Child Development, New York. http://www.ecdgroup.com/ download/ac1gsxxi.pdf. Accessed 25 Mar 2010

Noble Energy Solar Technologies Ltd. (NEST) (2005) Affordable solar lanterns to replace kerosene lamps. The Ashden Awards for Sustainable Energy. http://www.ashdenawards.org/winners/nest. Accessed 16 Jan 2010

Noble Energy Solar Technologies Ltd. (NEST) (2009) SolarNEST's blog. http://solarnest.wordpress.com/about/. Accessed 17 Jan 2010

Nouni MR, Mullick SC, Kandpal TC (2009) Providing electricity access to remote areas in India: niche areas for decentralized electricity supply. Renew Energy 34(2):430-434

Pullenkav JT (2010) Finance for local sustainable energy: the role of social investing, end-user finance and carbon finance in scaling up. SELCO Solar Light (P) Limited. http://www.sei.ashdenawards. 
org/presentations/files/Day_2_Presentation_3_SELCO.ppt. Accessed 20 Dec 2010

Raja JSD (2009) Lighting up lives. http://business.outlookindia.com/ article.aspx?261396. Accessed 20 Aug 2011

Ramani VV (2010) Interview, 27 January 2010, Hyderabad

Rehman IH, Kar A, Raven RPJM, Singh D, Tiwari J, Jha R, Sinha PK, Mirza A (2010) Rural energy transitions in developing countries: a case of the Uttam Urja initiative in India. Environ Sci Policy 13(4):303-311

Robben ACGM (1984) Entrepreneurs and scale: interactional and institutional constraints on the growth of small-scale enterprises in Brazil. Anthropol Quart 57(3):125-138

Rogers J, Hansen R, Graham S, Covell P, Hande H, Kaufman S, Rufin C, Frantzis L (2006) Innovation in rural energy delivery. Accelerating energy access through SMEs. A Navigant Consulting, Inc./Soluz, Inc. Study, Burlington/Chelmsford

Romijn HA, Caniëls MCJ (2011) Pathways of technological change in developing countries: review and new agenda. Dev Policy Rev 29(3):359-379

SELCO (2009) SELCO 2009: determining a path forward. Yale School of Management. Design and Social Enterprise Case Series. http://nexus.som.yale.edu/design-selco/. Accessed 9 Sep 2010

SELCO (2010) SELCO Business Plan 2006-2010. http://nexus.som. yale.edu/design-selco/sites/nexus.som.yale.edu.design-selco/files/ imce_imagepool/SELCO\%20Business\%20Plan\%202006-2010\% 20Nov.pdf. Accessed 30 Oct 2011

SELCO India (2005) Making a business from solar home systems. Ashden Awards for Sustainable Energy. http://www.ashdenawards. org/winners/selco. Accessed 12 Jan 2010

SELCO India (2007) Solar photovoltaic's enabling small businesses to develop. Ashden Awards for sustainable energy. http://www. ashdenawards.org/winners/selco07. Accessed 13 Jan 2010

SELCO India (2011) Company homepage. http://www.selcoindia.com/index.html. Accessed 12 Jan 2011

Shekhar H (2009) Interview, 24 December 2009, Auroville, Puducherry

Shukla S, Bairiganjan S (2011) The Base of Pyramid distribution challenge: evaluating alternate distribution models of energy products for rural Base of Pyramid in India. XIFMR Research, Centre for Development Finance

Smith BR, Stevens CE (2010) Different types of social entrepreneurship: the role of geography and embeddedness on the measurement and scaling of social value. Entrep Region Dev 22:575-598
Srivastava L, Rehman IH (2006) Energy for sustainable development in India: linkages and strategic direction. Energy Policy 34:643-654

Sud M, Van Sandt CV, Baugous AM (2008) Social entrepreneurship: the role of institutions. J Bus Ethics 85(1):201-216

The Economist (2010) The power to disrupt. Business innovation from emerging markets will change the rich world too. http://economist.com/node/15879393. Accessed 26 Oct 2011

THRIVE (2010) THRIVE. http://thrive.in/index.html. Accessed 14 Mar 2010

THRIVE (2011) THRIVE Energy Technologies Pvt. Ltd. http://thriveenergy.co.in/. Accessed 15 Aug 2011

Uppal A, Mahendra Y (2009) Eliminating light poverty: how a small Indian company created the best solar lantern in the world and took it to the bottom of the pyramid. Indian School of Business, Hyderabad

Uvin P (1995) Fighting poverty at the grassroots: paths to scaling up. World Dev 23(6):927-939

Uvin P, Miller D (1994) Scaling up: thinking through the issues. Global Policy Forum. http://www.globalpolicy.org/component/ content/article/177/31630.html. Accessed 30 Oct 2011

Van de Ven AH (1993) The development of an infrastructure for entrepreneurship. J Bus Ventur 8:211-230

Van de Ven AH (2005) Running in packs to develop knowledgeintensive technologies. MIS Quart 29(2):365-378

Westall A (2007) How can innovation in social enterprise be understood, encouraged and enabled? A social enterprise think piece for the Office of the Third Sector. Cabinet Office, Office of the Third Sector

Wheeler D, McKague K, Thomson J, Davies R, Medalye J, Prada M (2005) Creating sustainable local enterprise networks. MIT Sloan Manag Rev 47(1):33-40

Witkamp MJ, Raven RPJM, Royakkers LMM (2011) Strategic niche management of social innovations: the case of social entrepreneurship. Technol Anal Strateg Manag 23(6):667-681

Zahra AS, Rawhouser HN, Bhawe N, Neubaum DO, Hayton JC (2008) Globalization of social entrepreneurship opportunities. Strateg Entrep J 2:117-131

Zahra AS, Gedajlovic E, Neubaum DO, Shulman JM (2009) A typology of social entrepreneurs: motives, search processes and ethical challenges. J Bus Ventur 24(5):519-532 